\title{
The Attributes of Customer Needs Tenun Ikat SME for Competitive Market in Indonesia
}

\author{
Rita Ambarwati ${ }^{1}$, Andre Saputro ${ }^{2}$, Wiwik Sulistiyowati ${ }^{3}$ \\ \{ritaambarwati@umsida.ac.id ${ }^{1}$, andre.ridho.saputro@gmail.com ${ }^{2}$, wiwik@umsida.ac.id ${ }^{3}$ \} \\ Faculty of Economics and Business, Universitas Muhammadiyah Sidoarjo, Sidoarjo ${ }^{1}$ \\ Department of Technology Management, Institut Teknologi 10 Nopember, Surabaya ${ }^{2}$ \\ Engineering Faculty of Engineering, Universitas Muhammadiyah Sidoarjo, Sidoarjo ${ }^{3}$
}

\begin{abstract}
The development of economy in Indonesia will not be separated from the role of small and medium enterprises. Tenun Ikat industrial centers is one of a collection of tenun ikat artisans in Kediri that less can compete with other similar products. On the basis of problems that often occur in Small Medium Enterprise, related the fulfillment of customer satisfaction. This research provide the solution method of the selection criteriabased product development strategy of competitive advantage such as quality, cost, delivery, service, and morale. Method of collecting data with a detailed questionnaire on the Tenun Ikat customers and analysed by using Importance Performance Analysis based on the criteria of customer needs for competitive advantage. The results of this study indicate that the plot from the value of each attribute in a Cartesian diagram that influence customer satisfaction and support in winning market competition.
\end{abstract}

Keywords: Quality Cost Delivery Safety Morale; Importance Performance Analysis; Small Medium Enterprise.

\section{Introduction}

The success of SME in providing the best products to consumers includes a combination of goods and services in each ideal portion according to the company. The presentation of products in a broad sense is a challenge as well as an opportunity for operating production systems that must be carried out by SME. Starting from identifying consumer tastes to seeking all input requirements from suppliers to produce and distribute these products in accordance with the tastes of targeted consumers. Basically consumers expect to be able to obtain products that have benefits at an acceptable price level. To realize the desires of these consumers, each company strives optimally to use all its assets and capabilities to provide added value to consumer expectations. The implementation of this effort certainly has different cost consequences in each SME including its competitors.

In the beginning, the company only paid attention to the quality aspects of its products, but due to the development of the era and the tight competition of the business aspects of costs, delivery accuracy, and service from the company needed to be further studied. The success of company in long term depend on strategy developing product [1]. Therefore the criteria for Quality, Cost, Delivery, and Services are known or commonly called QCDS [2]. The research uses QFD method to determine attribute criteria of QCDS and AHP based market competition to determine market competition strategy [3]. As time goes on and the demands of global business competition, companies need other criteria to support their competitive advantage. 
Consumer awareness regarding aspects of safety and green manufacturing requires companies to change the paradigm of competitive advantage criteria by adding aspects of safety and morale that are closely related to the company's obligation to maintain the environment in each of its business processes [4]. Because of these demands, the competitive advantage criteria that are relevant to be used are QCDSM.

Tenun Ikat SME is one of a group of Tenun Ikat craftsmen in the City of Kediri, East Java, which has carried out business processes since 1989. In the center of the weaving industry there are 10 weaving craftsmen who can cover 270 workers, each of whom comes from residents surrounding area. Therefore the development of this potential industry is very important to do. In general, the attitude of each stakeholder of the weaving industry is a mutually supportive relationship for the growth and development of weaving SME.

Efforts to be able to compete with existing industries are very important for every company to do, therefore it is necessary for efforts to improve quality so that they can produce quality products and products that are in demand by consumers. Companies can choose how to compete, namely through the lowest prices or the most quality products. If a company has difficulty competing in prices, the company is better off using product quality or service quality in winning competition [5].

The price of a product or service is one of the determining factors in market demand. Price is a very important thing that is considered by consumers in buying a product. If consumers feel that they match the price offered, they tend to repurchase the same product.In the scope of business competition, every company must pay attention to aspects of the main concern of competition itself such as quality, features, functions, product reliability, services provided, product stock availability, company image and reputation, mastery of the marketing team's knowledge of its products and technology, and competitive prices [2].

Competitive advantage basically grows from the value or benefits of the company to the buyers where the value is more than the cost that the company must incur to create it. It is this value or benefit that the buyer is willing to pay, and the superior value comes from offering a lower price than the competitor's price with equal benefits or unique benefits that exceed the price offered [4]. Competitive advantage is the superiority of competitors that is obtained by offering lower value or by providing greater benefits because the price is higher [6].

Based on the problems faced by these SMEs, this study will solve the problem of how a priority to meet consumer demand can be made using the QCDSM concept in choosing a product design strategy to maintain the competitive advantage that is right for the survival of Bandar Kidul City Kediri SME. measurement of customer needs in SMEs in Indonesia, the level of quality and customer loyalty has not been done much. However, research related to the development of new products that meet the market expectations of the SMEs industry in Indonesia, especially for textile SMEs, has never been done. This study aims to develop SME Tenun Ikat products to survive in the era of global industrialization in Indonesia.

\section{Methodology}

The initial stage of data collection is determining the attributes of market competition that will be used. The attributes in this study are weaving attributes that are consumer needs and are used to determine the quality characteristics of woven products, including those obtained from several literature, direct interviews with consumers and distributors. Determination of weaving product quality attributes refers to several existing theoretical frameworks, namely the 
theoretical framework presented by Kotler [8] and Wijaya [9]. The selected attributes are based on the criteria of quality (Q), cost (C), delivery (D), safety (S), and morale (M). In determining these indicators combine the basic quality criteria that Kotler (1997)[8] has conveyed with the suitability of the paradigm and business market environment of the Bandar Kidul Ikat Ikat product in Kota Kediri. Determination of product quality attributes is as follows. Data collection research was conducted using the help of research instruments, namely questionnaire research as many as 85 questionnaires. This questionnaire is an assessment of respondents or consumers on the level of reality and the level of expectations of the attributes of competitive advantage based on QCDS using the Likert scale. In addition, technical response data collected from interviews with owners of SMEs were also collected related to the needs of consumers who had been processed. After the questionnaire data is obtained, the next step is to test the validity and reliability. Next is the preparation of the Importance-Performance Analysis (IPA). (a)One method that can be used is Importance Performance Analysis (IPA) because it has several advantages compared to other methods. These advantages, among others, can show product / service attributes that need to be increased or reduced to maintain customer satisfaction, the results are relatively easy to interpret, the scale is relatively easy to understand, and requires low costs [10]. Science is a procedure to show the relative importance of various attributes to the performance of an organization or company. (b) the Importance Performance Analysis (IPA) method is an easy application technique for managing attributes from the level of importance and level of implementation itself that are useful for the development of effective marketing programs [11].

Table 1. Competitive advantage indicator

\begin{tabular}{lcl}
\hline Indicator & Criteria & Explanation \\
\hline (1)Price Conformity & C+Q & The price is offered according with the quality of the product \\
(2)Endurance & $\mathrm{Q}$ & The durability of the product \\
(3)Product Packaging & $\mathrm{Q}+\mathrm{D}$ & The product packaging attractive to consumers \\
(4)Trademark & $\mathrm{D}$ & The symbols and writing of SME's trademarks \\
(5)Product Size & $\mathrm{Q}$ & The size of the product \\
(6)Dyes & $\mathrm{S}$ & The dye harmful to consumers \\
(7)Product Color & $\mathrm{Q}$ & The color of the product attractive to consumers \\
(8)Packaging Material & $\mathrm{M}$ & The packaging material environmentally friendly plastic \\
(9)Product availability & $\mathrm{D}$ & The products always available at outlets \\
(10)Product Safety & $\mathrm{S}$ & The products safe to use for consumers \\
(11)Product Delivery & $\mathrm{D}$ & The product delivery always on time \\
(12)Dangerous waste & $\mathrm{M}$ & The production system produce dangerous waste \\
(13)Environmentally friendly & $\mathrm{M}$ & The business system of SME's friendly to the environment \\
(14)Design Product & $\mathrm{Q}+\mathrm{D}$ & The design product is expected by consumers \\
\hline
\end{tabular}




\section{Discussion}

The results of data collection and processing of the level of consumer interest (importance to customer) are the result of processing IPA from the value of customer satisfaction and the value of the interests of the customer. The use of the results of the Importance-Performance Analysis (IPA) aims to find out what things are influential and become the main expectations of customers in obtaining products or services from UMKM Weaving Bonds in Bandar Kidul, Kediri City. Based on the results of the questionnaire that has been disseminated, the level of customer satisfaction and the level of customer interest is obtained as in table 2 .

Table 2. The Level of Satisfaction-Importance Customer

\begin{tabular}{lccl}
\hline \multicolumn{1}{c}{ Attribute } & $\begin{array}{c}\text { Level of } \\
\text { satisfaction }\end{array}$ & $\begin{array}{c}\text { Level of } \\
\text { Importance }\end{array}$ & $\begin{array}{c}\text { Importance } \\
\text { to Customer }\end{array}$ \\
\hline Price Conformity & 1,98 & 4,23 & 0,47 \\
Endurance & 2,25 & 4,33 & 0,52 \\
Product Packaging & 1,98 & 4,22 & 0,47 \\
Trademark & 1,98 & 4,27 & 0,46 \\
Product Size & 2,38 & 4,52 & 0,53 \\
Dyes & 2,50 & 4,65 & 0,54 \\
Product Color & 2,18 & 4,35 & 0,50 \\
Packaging Material & 2,22 & 4,38 & 0,51 \\
Product availability & 2,10 & 4,32 & 0,49 \\
Product Safety & 2,18 & 4,37 & 0,50 \\
Product Delivery & 2,12 & 4,35 & 0,49 \\
Dangerous waste & 1,97 & 4,25 & 0,46 \\
Environmentally & 2,12 & 4,40 & 0,48 \\
friendly & 3,88 & 4,78 & 0,81 \\
Design Product & 2,28 & 4,39 & \\
\hline Rata-rata & \multicolumn{3}{c}{} \\
\hline
\end{tabular}

Once the results are obtained by averaging the values of any attributes, the next step is to create a Cartesian diagram regarding the position of the placement of data based on Importance-Performance Analysis (IPA). The results of the plot from the value of each attribute in a Cartesian diagram (Figure 1). An explanation for each quadrant of a Cartesian diagram is as follows.

- the Quadrants A, the region that contains the attributes considered important by customers but in reality these attributes have not been in accordance with what is expected (consumer satisfaction levels are still low). In this region the company make improvements continuously in order for performance in this quadrant. There is no attribute that meets the requirements in this quadrant.

- Quadrant B, the region that contains the attributes considered important by customers and the attributes that are considered by the customer is in compliance with the perceived relative satisfaction rate so much higher. The attributes that are included in this quadrant is the size attribute of the product (5), dye (6), design product (14).

- Quadrant $\mathrm{C}$, the region that contains the attributes that are considered less important by customers and in fact it performs less well. Included in this quadrant is to attribute the price of conformity (1), (3) product packaging, trademarks (4), product color (7), packaging material (8), product availability (9), product safety (10), product delivery (11) and dangerous waste B3 (12).

- Quadrant $\mathrm{D}$, the region that contains the attributes that are considered less important by customers and the perceived excessive. Included in this attribute is the attribute of environmentally friendly(13). 


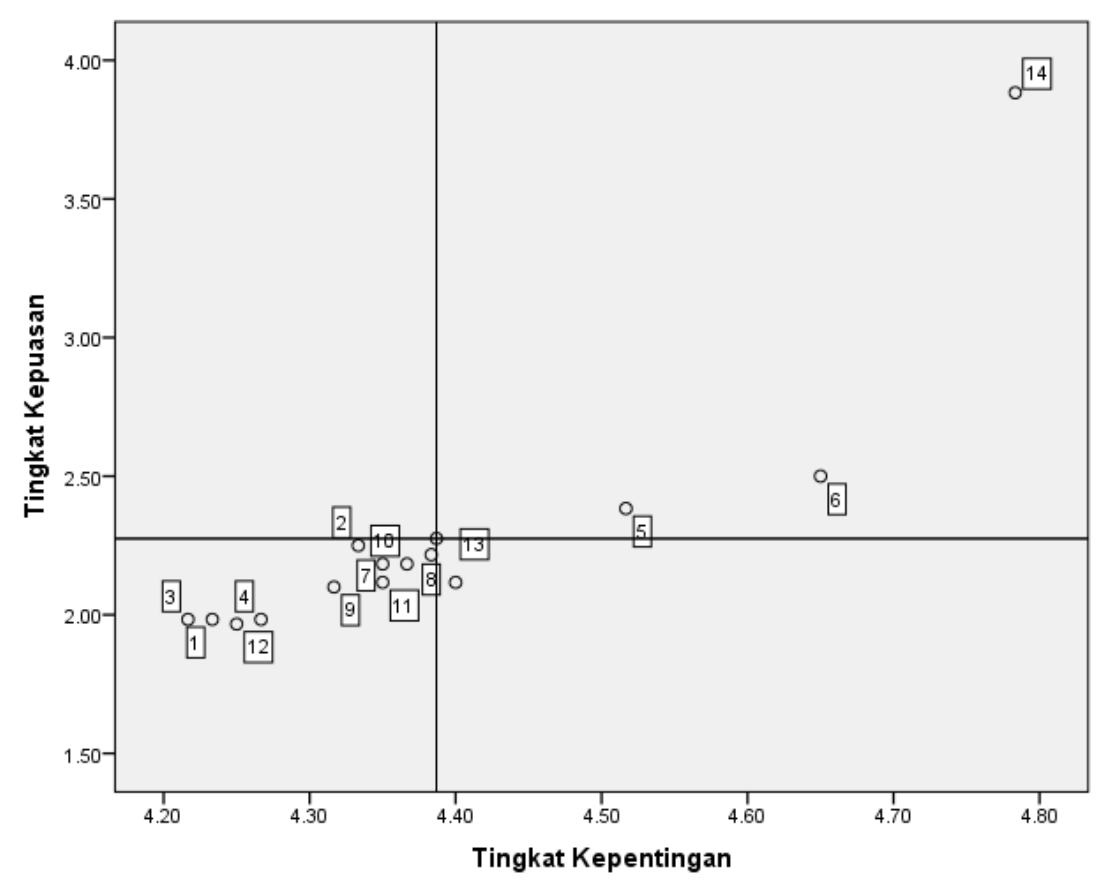

Fig. 1. Cartesian Diagram (Importance Performance Analysis)

Most of the attributes are in the quadrant $\mathrm{C}$, that is considered less important by customers and in fact it performs less well. Improvement on the attribute then it will hopefully improve consumer satisfaction from SMEC Tenun Ikat Kediri. Some attributes are in quadrant B that contains the attributes considered important by customers and compliance with the perceived relative satisfaction rate so much higher.

\section{Conclusion}

The selected attributes in this research are based on the criteria of quality (q), cost (c), delivery (d), safety (s), and morale (m). The attributes in Cartesian diagram from Importance Performance Analysis will be able to increase the number of consumers. They find out what things are influential and become the main expectations of customers in obtaining products or services. Criteria for Quality (Q), Cost (C), Delivery (D), Safety (S) and Morale aspects (M) are factors that influence customer satisfaction and support in winning market competition. In the beginning, the company only paid attention to the quality aspects of its products, but due to the development of the era and the tight competition of the business aspects of costs, delivery accuracy, and service from the company needed to be further studied.

\section{References}

[1] Ambarwati, R. (2018). Generating Competitive Priority Strategy in Transformer Industry. Proceedings of the Annual Conference on Social Sciences and Humanities (ANCOSH 2018),

[2] Fahey, L. (1999). Competitor Analysis: Out Witting, Out Maneuvering, and Out Performing. 
[3] De Felice, F., \& Petrill, A.. (2010). A multiple choice decision analysis: an integrated QFDAHP model for the assesment of customer needs. International Journal of Engineering, Science and Technology, 2(9).

[4] Jonny. (2012). Efforts to Decrease Medium-sized Glass Loss Cases Through the Application of the Quality Control Circle (QCC) Method in the Nutrition Unit, ABC Hospital, Jakarta. COMTECH.

[5] Zeithaml, V., \& Bitner, M. (1990). Service Marketing. Ney Jersey: The McGraw-Hill Companies, Inc.

[6] Porter, M. E. (2003). Clusters and the New Economics of Competition.

[7] Kotler, P. (2003). Marketing Management. New Jersey.

[8] Kotler, P. (1997). Marketing Management, Millennium Edition. New Jersey: Prentice Hall International, Inc.

[9] Wijaya, T. (2011). SERVICE QUALITY MANAGEMENT, Servqual Design, QFD, and Kano: Accompanied by Application Examples in the Research Case. Jakarta.

[10] Yola, M. (2013). Analysis of Consumer Satisfaction on Service Quality and Product Prices in Supermarkets Using the Importance Performance Analysis (IPA) Method. Industrial Systems Optimization Journal. 12 (12): 301-309.

[11] Muharastri, Y. (2008). Analysis of Real Good Brand UHT Milk Consumer Satisfaction in Bogor City. Essay. Faculty of Agricultural Technology. Bogor Agricultural Institute. Bogor. 